\title{
Paradoxical role of Id proteins in regulating tumorigenic poten- tial of lymphoid cells
}

\author{
Sumedha Roy (凶), Yuan Zhuang \\ Department of Immunology, Duke University Medical Center, Durham, NC 27710, USA \\ (C) The Author(s) 2018. This article is published with open access at link.springer.com and journal.hep.com.cn
}

\begin{abstract}
A family of transcription factors known as Id proteins, or inhibitor of DNA binding and differentiation, is capable of regulating cell proliferation, survival and differentiation, and is often upregulated in multiple types of tumors. Due to their ability to promote self-renewal, Id proteins have been considered as oncogenes, and potential therapeutic targets in cancer models. On the contrary, certain Id proteins are reported to act as tumor suppressors in the development of Burkitt's lymphoma in humans, and hepatosplenic and innate-like $T$ cell lymphomas in mice. The contexts and mechanisms by which Id proteins can serve in such contradictory roles to determine tumor outcomes are still not well understood. In this review, we explore the roles of Id proteins in lymphocyte development and tumorigenesis, particularly with respect to inhibition of their canonical DNA binding partners known as $\mathbf{E}$ proteins. Transcriptional regulation by $\mathbf{E}$ proteins, and their antagonism by Id proteins, act as gatekeepers to ensure appropriate lymphocyte development at key checkpoints. We re-examine the derailment of these regulatory mechanisms in lymphocytes that facilitate tumor development. These mechanistic insights can allow better appreciation of the context-dependent roles of Id proteins in cancers and improve considerations for therapy.
\end{abstract}

Keywords Id proteins; lymphoma; leukemia; T cells; B cells; tumor suppressor; oncogene

\section{Introduction}

Since their discovery almost three decades ago, Id proteins have been associated with the maintenance of a state of anaplasia or dedifferentiation in cells [1-5]. They are known to facilitate this through inhibition of functions of various classes of ubiquitous and tissue-specific helix-loop-helix $(\mathrm{HLH})$ transcription factors, including E proteins, ETS, PAX, MYOD and RB proteins. The role of Id proteins in preventing cell differentiation and promoting stem cell behavior has begged the question regarding their potential in giving rise to cancer stem cells, and therefore as oncogenes [3-6]. In support of their oncogenic functions, Id proteins have been reported to have high expression in multiple tumor types, and to contribute to anaplasia, angiogenesis and metastasis of tumors. The upregulation of Id proteins can be mediated by upstream oncogenic events that promote their overexpression, increase their stability, or abolish their suppression by tumor suppressors. Id protein dysregulation

Received March 10, 2018; accepted June 26, 2018

Correspondence: Sumedha Roy, Sumedha.roy@dm.duke.edu, sumedharoy@gmail.com has been implicated in causing a wide range of malignancies, including, but not limited to, tumors in the bladder, breast, prostate, liver and brain (summarized in [5]). However, gain-of-function alterations in Id genes in human tumors, that can conclusively verify the oncogenic nature of Id proteins, are a key piece to the puzzle that is still missing. Nonetheless, efforts spearheading the inhibition of Id proteins as potential therapeutic targets are underway $[4,5,7]$. The notion of Id proteins acting as oncogenes, however, has also now been challenged by recent data demonstrating their tumor suppressive roles in some cancers, most prominently in Burkitt's lymphoma. The overall role of Id proteins in normal development and tumorigenic pathways has been reviewed extensively [1-6].

Considering the different potential interaction partners and cell-specific functions of Id proteins, it is hard to uniformly and exhaustively predict the role of Id proteins in distinct tumor types. Blood cancers, including lymphomas and leukemias, are estimated to constitute up to $8 \%$ of new cancer cases diagnosed this year (Lymphoma and Leukemia Society statistics). In this review, we summarize the underlying pathways that drive either Id-mediated tumorigenesis or tumor suppression in lymphocytes. E proteins are the most typical interaction partners of Id 
proteins in lymphocytes, where these transcription factors are highly expressed, and play crucial roles in regulating cell differentiation and proliferation through direct inhibition, and mutual regulatory feedback loops. Additionally, phenotypic similarities between lymphocyte-derived tumors that develop in Id-overexpression and E protein null mutant mice suggest that Id proteins often mediate their functions in these tumors through inhibition of $\mathrm{E}$ protein activity [3].

\section{Antagonism between $E$ and Id proteins}

Id proteins, including Id1, Id2, Id 3 and Id4, are members of class V HLH proteins that can dimerize with other HLH protein classes, but unlike their binding partners, lack a DNA binding domain. They possess structural and conformational flexibility that is necessary for them to interact with different binding partners. All four Id protein family members share highly conserved HLH domains, but have differences in the $\mathrm{N}$ - and $\mathrm{C}$-terminals, which can allow them to bind to diverse partner protein classes, albeit with varying binding preferences [4,7-9]. Among the different interaction partners, E proteins and the retinoblastoma protein, $\mathrm{RB}$, are the only ones that are found to physically interact with Id proteins under physiological and disease conditions in vivo, as well as influence the expression of Id proteins. In this regard, the interaction of Id 2 and RB is also suggested to be crucial for allowing uninhibited E protein activity [4].

E protein family members, E12, E47, HEB and E2-2, are classified as class I HLH proteins, and serve as key transcriptional regulators. These canonical interaction partners of Id proteins [4] are more commonly referred to as basic helix-loop-helix (bHLH) transcription factors because of the additional basic DNA binding region. These transcription factors form homo- or heterodimers with other factors through the HLH domains, and simultaneously identify and bind to E-box motifs in the regulatory regions of genes to facilitate their transcriptional activation or repression. The interaction between the HLH Id proteins and bHLH E proteins precludes the DNA binding ability of the latter, making Id proteins potent inhibitors of $E$ protein function. Interestingly, the antagonistic interaction between $\mathrm{E}$ and Id proteins is utilized as gatekeepers or natural "brakes" in lymphocyte development, such that there is halt in progression into the next stage of development or maturation, until appropriate signals that regulate their expression tip the $\mathrm{E} / \mathrm{Id}$ protein balance to allow developmental progression accompanied by the expression of appropriate target genes for the next stage. Overall these "brakes" ensure smooth regulation of cell proliferation and differentiation during development. The appropriate expression of, as well as the interaction between, $\mathrm{E}$ and Id proteins tightly control developmental outcomes, and therefore, their dysregulation causes the brakes to "fail," often resulting in cells being predisposed to malignant transformation. It is crucial to understand the various factors that can determine physiological versus tumorigenic outcomes driven by $\mathrm{E}$ and Id proteins (Fig. 1).

While we do not wish to enumerate all observations that have led to predominant beliefs about the oncogenic roles
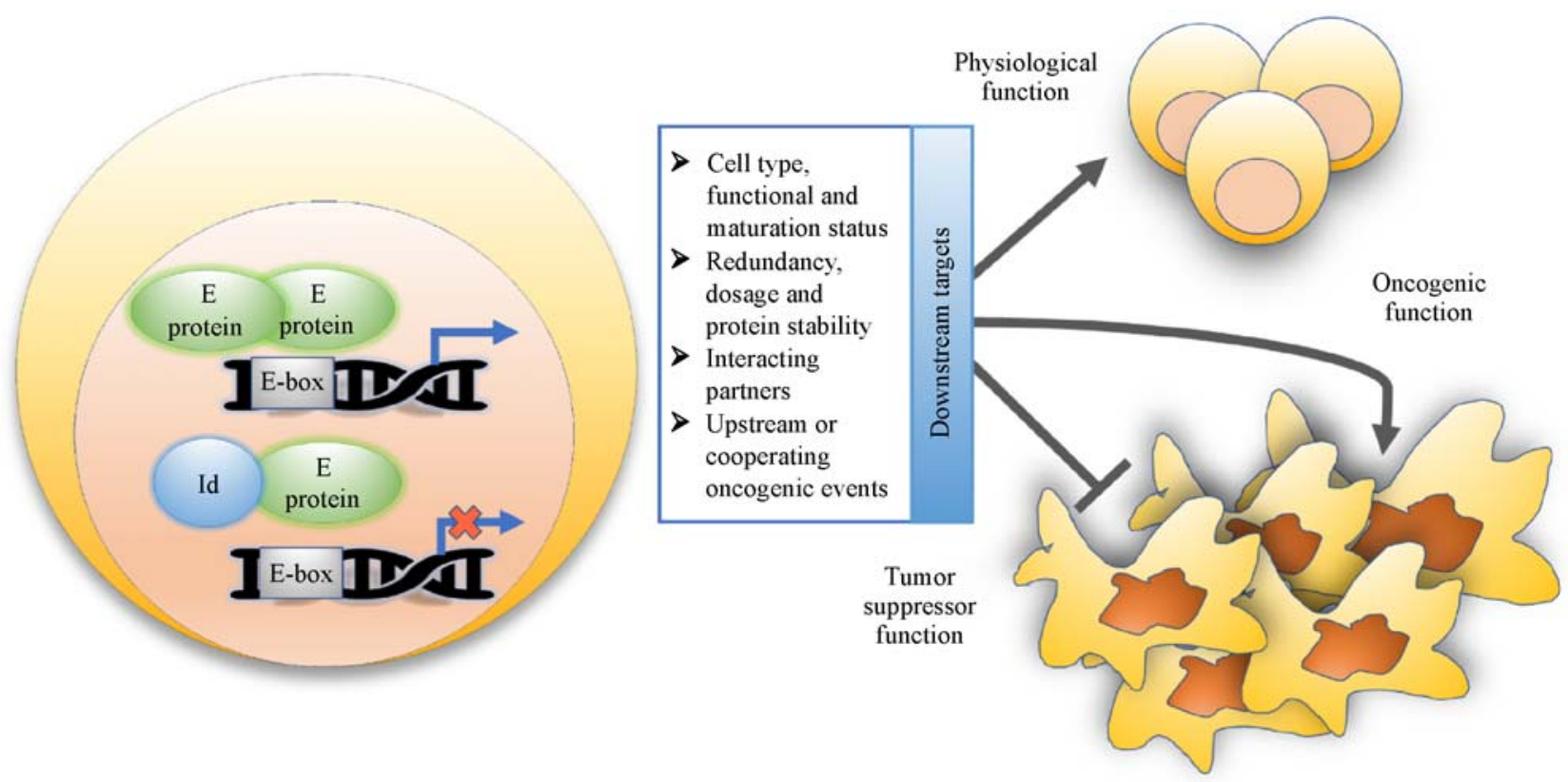

Fig. 1 Factors that influence context-dependent roles of E and Id proteins in development and cancer. 
of Id proteins, and corresponding tumor suppressor roles of E proteins, it is worth mentioning a few of them to provide a historical perspective. The observation of induction of high Id expression in cells that are undifferentiated and proliferating supported the idea that Id proteins could contribute to anaplasia [3,10]. Even though just overexpression of Id proteins was not enough for immortalization of cell lines, it supported a pluripotent, stem cell-like fate in the presence of leukemia inhibitor factor (LIF) $[4,11]$. It was proposed that Id 2 and Id 3 may act together to control cyclin E (Ccnel) and cyclin A (Ccna2) [1]. Id proteins were also found to suppress the regulators of cell senescence, such as $R b$ and cyclin dependent kinase inhibitors $p 16 I N K 4 a, p 21$ and $p 27$, which can be activated by Ets and $E$ protein family members $[12,13]$. In stark contrast, E2A was found to activate $p 21$, and to play a role in apoptosis and growth suppression in NIH3T3 cells $[14,15]$. A forced MyoD-E47 dimer that can no longer bind to Id proteins can overcome the effects of Id1 overexpression to promote differentiation in target cells $[1,16]$. Id protein half-life is also extended by binding to E2A [17]. Therefore, the dynamics between $\mathrm{E}$ and Id proteins is crucial in maintaining a balance between cell proliferation, survival and differentiation either through their direct regulation of relevant downstream targets, or through indirect inhibition of binding to other HLH interaction partners, such as RB and ETS proteins.

In the sections below, we discuss the roles of $\mathrm{E}$ and $\mathrm{Id}$ proteins in regulating B and T lymphocyte development, as well as how their function is hijacked to cause lymphoma and leukemia in humans and mice. This derailment of $\mathrm{E}$ and Id proteins can change their roles from promoting hematopoietic differentiation to triggering oncogenic proliferation.

\section{Physiological role of E and Id proteins in B cell development}

E2A is essential for early stages of B cell development, as it is necessary for instructing a lineage-specific program [18-25]. E proteins induce the expression of FOXO1, which then works with E2A to induce EBF1, and all three activate PAX5 for B cell lineage determination [26]. As a result, a deficiency in E2A restricts B cell development at the pre-pro-B cell stage, which can however be rescued by forced Pax5 expression [27]. E proteins also support the survival and proliferation of pro-B cells [28]. A proliferative burst may be activated by a slight downregulation of $\mathrm{E}$ protein activity that follows pre-BCR signaling. E proteins can also regulate cell proliferation through cyclin D3 [25]. On the other hand, Id3 can induce apoptosis in progenitor B cells in a caspase-dependent fashion [29].

While E proteins play critical roles in early steps of B cell development, it has been shown that E proteins are dispensable for the generation and maintenance of mature, splenic B cells [27]. Nonetheless, E proteins regulate immunoglobulin $\kappa$ locus rearrangements, somatic hypermutation (SHM) and class switch recombination (CSR). Their absence impairs germinal center (GC) B cell development through a mechanism that is independent of CSR, survival and proliferation, but is not fully characterized [27]. Id 3 expression is low in GC B cells, but is essential to allow expression of genes for BCR signaling, cytokine signaling and CSR. Id3-deficient GC B cells are found to have a proliferation defect, which is important for CSR [30].

\section{Tumor suppressor Id proteins counteract oncogenic E2A activity in $B$ cell lymphomas}

Burkitt's lymphoma (BL), typically characterized by a Myc translocation, is a type of non-Hodgkin lymphoma derived from malignant transformation of GC B cells $[31,32]$. It represents the first cancer type where the documentation of loss of function mutations in the $I d 3$ gene questioned the idea of Id proteins acting as only oncogenes [33-35]. Frequent mutations in $I d 3$ are found in $\mathrm{BL}$ patients, more frequently in adults, than in pediatric $\mathrm{BL}$ [36]. Tcf3 (gene encoding E2A), which is otherwise highly expressed in GC B cells, as well as its target cell cycle regulator gene $C$ cnd 3 (cyclin D3), are also often mutated in BL [33-35]. While mutations in Id3 are more common than mutations in $T c f 3$, some BL patients have mutations in both. The $I d 3$ mutations are usually bi-allelic inactivating mutations that block its binding to E2A [33]. Tcf3 mutations on the other hand are mono-allelic, and most commonly affect the HLH dimerization domains of E47, but not E12. Some Tcf3 mutants have broad binding profiles similar to WT E2A, but rare mutants can have slightly altered binding preference with respect to the Ebox motif, thereby regulating different downstream targets [33]. BL samples that do not have mutations in Id3 have significantly higher expression of $T c f 3$, suggesting an important role for E protein-mediated tumorigenesis [34]. Tcf3 expression has also been shown to be important for the survival of BL cells.

Interestingly, these lymphoma cells still retain some genes pertaining to their GC identity. Genes such as Pou 2af1, Cxcr4, Ltb, which are normally expressed in GC B cells, are overexpressed in Tcf3 mutant BL cells. In terms of cell cycle, Tcf3 mutants upregulate $C c n d 3$ and $E 2 f 2$ and downregulate $R b 1$ [35]. Ccnd3 is important for cell cycle progression in GC B cells [37,38], and is mutated in a variety of $\mathrm{BL}$ forms, albeit at a lower frequency than other mutations [35]. These Ccnd3 mutants have survival and proliferative advantage. Along similar lines, deleterious mutations are also found in the CDK6 inhibitor p16, and treating BL cell lines with CDK6 inhibitors induces cell death [35]. Overall, increased proliferation and survival of 
the malignant $\mathrm{GC} \mathrm{B}$ cells in $\mathrm{BL}$ is promoted through TCF3-mediated Ccnd3 upregulation and PI3K upregulation through SHP-1 repression downstream of tonic BCR signaling [33-35,39]. E2A can also promote survival in transformed pro-B cells independent of $B c l 2$, through the inhibition of caspase activity [40]. These expression profiles, and the dependency on E2A for BL survival, suggest that the normal GC B cell program is hijacked for tumorigenesis.

Even though Myc translocation next to one of three immunoglobulin loci is a hallmark in BL, and is capable of regulating cell cycle, growth and apoptosis, it is not enough to cause malignant transformation $[41,42]$. Myc translocation is therefore thought to be an early initiating event. $I d 3$ has also been mapped to be located in the minimal region of recurrent imbalance with respect to the Myc translocation, potentially explaining recurrent mutations in the gene [34,43]. Based on the evidence presented above, Id 3 inactivation combined with Myc translocation may be considered a more representative hallmark of BL. Even then, a small percentage of patients with other nonBL lymphomas that have Myc translocations are reported to have $I d 3$ mutations as well [34]. The $I d 3$ mutations seem to be downstream of the Myc event, since a subset of B cell lymphomas that resemble BL features and gene expression patterns but don't have Myc translocation don't show mutations in Id3 [44]. Myc also has dual roles in general in regulating cell cycle as well as apoptosis. Yet, the latter suppressive function is somehow overcome in $\mathrm{BL}$, perhaps through the inactivating mutations in Id3 [45]. Inhibition of Pim3, a target of Myc in BL cell lines, leads to cell death in Myc-induced lymphomas independent of caspase activity [46].

Surprisingly, negative feedback regulation is still active in $\mathrm{BL}$, as $T c f 3$ mutants have increased expression of $I d l$, $I d 2$ and $I d 3$ [35]. This upregulation could be mediated by either E2A or Myc, since both can directly regulate Id proteins. $I d 2$ is found to be upregulated in $\mathrm{E} \mu-\mathrm{Myc} \mathrm{BL}$, but its loss doesn't impact the survival or incidence of these lymphoma cells [47]. However, cells transfected to overexpress wild-type $I d 3$ seemed to have disadvantaged cell growth in cell culture, reflecting the tumor suppressor function of $I d 3$ in BL [34]. Id4 expression is reduced through hypermethylation in Raji human BL cell line. Use of a demethylating agent reverses that to induce Id4 expression, which leads to cell cycle arrest and apoptosis [48]. TGF- $\beta$, which can induce Id3 to inhibit growth in progenitor B cells [29], can also inhibit growth of BL and B cell lymphoma cell lines by repression of E2f1, accompanied by activation of Smad signaling, p38 MAPK, and an increase in $I d 1$ and $I d 2$ expression $[49,50]$.

In contrast, the role of Id3 in diffuse large B cell lymphomas (DLBCL), another type of mature B cell nonHodgkin lymphoma, is yet to be fully ascertained. DLBCL is further classified based on gene expression profiling and different stages of differentiation as being derived from germinal center $(\mathrm{GC}) \mathrm{B}$ cells, activated $\mathrm{B}$ cells $(\mathrm{ABC})$ and primary mediastinal $\mathrm{B}$ cell lymphomas (PMBL). A recent study characterizing mutations in a large cohort of DLBCL patients did not find any mutations in Id3 [51]. On the other hand, two other studies have reported a small percentage of patients from all three DLBCL subtypes to have mutations in $I d 3$ that affect its HLH region [39,52]. However, it remains to be determined if Id3 plays similar tumor suppressive roles in these DLBCL cases [53]. One of the studies also found $T c f 3$ mutations that altered DNA binding specificity, whereas the other noted Ccnd 3 mutations among some DLBCL patients. When comparing the mutations in BL to DLBCL, it is crucial to note that the clinical diagnosis and classification of lymphomas as $\mathrm{BL}$ or DLBCL can strongly bias these results. Even though the World Health Organization (WHO) has laid out guidelines regarding the physiology and gene expression patterns that can be used to distinguish between these two, some mature B cell lymphomas, especially those derived from GC B cells, are hard to classify as either, and are placed in a third category known as B cell lymphoma unclassifiable (BCL$\mathrm{U})$. Given the contradictory reports on $I d 3$ mutations in DLBCL, $I d 3$ is not an ideal mutation to distinguish between BL and DLBCL. Recurrent Id3 mutations are found in lymphomas classified as BCL-U, as compared to those classified as true DLBCL [54]. Combined mutations in Id3-Ccnd3-Tcf3 have been suggested as a marker used to re-classify borderline BL/DLBCL cases as BL [39]. The age of patients in each study must also be considered since Id 3 mutation burden correlates with age [36,39]. Due to these reasons, the role of Id proteins in DLBCL cases remains ambiguous.

The discordance between $I d 3$ mutations in $\mathrm{BL}$ and DLBCL may partly be explained by the type of GC B cells they are derived from [45,55-57]. During the germinal centre reaction, activated $\mathrm{B}$ cells undergo repetitive cycles between somatic hyper mutation (SHM) and proliferation in the dark zone (DZ), and class switch recombination (CSR) and positive selection in the light zone (LZ). The SHM and CSR recombination events at the immunoglobulin loci mediated by activation-induced cytidine deaminase (AID) predispose GC B cells in both $\mathrm{LZ}$ and $\mathrm{DZ}$ to translocation events and tumorigenesis [58-60]. Based on gene expression patterns, BL cells have been found to resemble dark zone GC B cells, whereas DLBCL and most other GC-derived B cell lymphomas resemble light zone GC B cells [55,61]. DZ GC B cells, or centroblasts, are characterized by their high proliferation rate, and high expression of E2A and its target Ccnd3 [55,62]. Besides cell proliferation, E2A has also been shown to preferentially drive expression of typical genes important for centroblasts [62]. Id3, on the other hand, is upregulated by a negative feedback loop to keep $\mathrm{E}$ protein activity in check, and reduces with each cell cycle [63]. Interestingly 
however, Myc, is typically expressed only when positively selected centrocytes are moving back to the DZ, where it is again suppressed [64,65]. Myc translocation patterns in sporadic BL suggest derivation from CSR events $[66,67]$. Therefore, one possibility is that low levels of AID activity $[59,60,68]$ induce a Myc translocation in this window of transition from $\mathrm{LZ}$ to $\mathrm{DZ}$, such that the cells undergo proliferation and further mutations upon reaching the DZ, ultimately leading to malignant transformation. Given the important physiological function of E2A in centroblasts, there might be a selection pressure among transformed cells for mutations that have enhanced E2A activity, allowing the cells to inherit their normal transcriptional identity and proliferative capacity. As a result, loss-offunction $I d 3$ mutations in centroblasts are likely to be selected for in the case of BL pathogenesis, in addition to the recurrent imbalance in the $I d 3$ locus upon Myc translocation [34]. However, it is possible to alternatively envision $I d 3$ or $T c f 3$ mutation as the initiating oncogenic event for BL. In this case, the high E2A activity in mutated, highly proliferating DZ cells can potentially prime the $M y c$ locus for a secondary translocation event, supported by AID expression and SHM. On the other hand, the selection pressure of oncogenic mutations in LZ centrocytes leading to DLBCL pathogenesis is likely to be different from BL, leading to frequent mutations in Bcl6 [69]. In support of preferential E2A function in centroblasts but not centrocytes, E2A is found to be important for BL survival, but does not affect DLBCL cell line survival [35]. Lymphomas that have intermediate phenotype between $\mathrm{BL}$ and DLBCL, or double-hit with Myc and Bcl2 and/or Bcl6, also tend to have frequent $I d 3$ mutations $[53,54]$.

\section{Oncogenic roles of Id proteins in B cell lymphomas}

As highlighted in Fig. 1, the subtype of cells, and their functional and activation status, can determine the type of role played by $\mathrm{E}$ and Id proteins in lymphomas derived from those cells. While Id3 seems to play a tumor suppressor role in GC B cells that give rise to $\mathrm{BL}$ and perhaps GC B DLBCL, it may play oncogenic roles in other subtypes of B cell lymphomas. For instance, high expression of $I d I$ and $I d 3$ genes in $\mathrm{B}$ cell adult lymphoblastic leukemia (B-ALL) leads to poor prognosis in adult patients [70]. Id4 has also been found to be overexpressed as a result of a translocation in B-ALL [71]. Multiple inactivating mutations in $\operatorname{Prdm} 1$ prevent Id3 suppression, such that $I d 3$ expression is always on in $\mathrm{ABC}$ DLBCL [72]. Follicular lymphomas upregulate $I d 2$ compared to healthy GC B cells [73].

While most B cell-derived lymphomas maintain expression of B cell factors, the loss of the B cell-specific program is a typical characteristic of mature B cells that give rise to Hodgkin-Reed/Sternberg (HRS) cells in classical Hodgkin's lymphoma (HL). Id2 is highly overexpressed in HL, perhaps due to chromosomal gain, and contributes to the block in the B cell program [74]. This overexpression of Id2, along with ABF-1 (activated B cell factor 1), antagonizes E2A, resulting in reduced expression of B cell-specific genes like Pou2f2, Cd19, Aicda, Cd79a, $E b f$ and upregulation of $\mathrm{T}$ cell-specific genes such as Gata3, Tcf7, Maf, Tbx21, Csf1r. B cells are also found to hyperproliferate in mice lacking one copy of E2A [75,76]. High Id 2 expression is considered a marker for HL [77], and an increase in Idl expression is proposed to be a marker for cancer-initiating cells in HL [78]. Primary effusion lymphoma (PEL) is a type of non-Hodgkin lymphoma that is derived from post GC B cells that lose their B cell-specific genes to more closely resemble Hodgkin lymphomas. PEL samples are also found to lose E protein activity, partly due to the upregulation of Id2 and ABF-1. E2A overexpression leads to induction of apoptosis, suggesting an Id-mediated oncogenic function that suppresses E protein activity [79].

\section{Oncogenic roles of $E$ proteins in B cell lymphomas}

The activating mutations in the E2A HLH region, that prevent Id-mediated suppression in BL patients are reflective of the oncogenic role of $\mathrm{E}$ proteins in BL. Nearly $50 \%$ of MALT (mucosal-associated lymphoid tissue) lymphoma cases, derived from marginal zone memory B cells aberrantly express $T c f 3$, even though it is not a memory cell marker, and may associate with poor treatment response [80]. There are translocations observed in B-ALL patients that give rise to oncogenic E2A fusion proteins. The fusion of E2A with HLF (hepatic leukemia factor) is found to contribute to B-ALL formation, particularly from pro-B cells [81]. E2A has been found to promote survival in transformed pro-B cells through the inhibition of caspase activity, and can therefore function as an oncogene in these cells [40]. In such patients, normal E2A targets are affected, but new oncogenic targets may also emerge. E2A is sufficient to drive the tumor, as long as it is overexpressed and/or dimerized with the fusion partner. The fusion protein requires both the E2A transactivating domain and the HLF basic region/leucine zipper dimerization domain [81,82]. Interestingly, transgenic mice expressing E2A-HLF have B and T cell maturation defects and give rise to T cell lymphomas [81]. Expressing the E2A-HLF fusion protein in $3 \mathrm{~T} 3$ cells correlates with cell growth or density, supporting its oncogenic function. E2A-PBX1 is another fusion protein identified in humans with the pre-B cell ALL [82]. The fusion protein derived from the transactivating domain of E2A and DNA binding domain of homeobox gene PBX1 was originally identified 
in human pediatric pre-B cell leukemias. The fusion protein is not sufficient to give rise to leukemia without secondary mutations since the premalignant cells are found to proliferate more, but also with more apoptosis $[83,84]$. E2A also lies in the chromosomal translocation breakpoint in pre-B cell leukemia, which leads to a chimeric fusion such that the dimerization and DNA binding domains of E2A are replaced by the DNA binding domain of the homeobox protein [85]. In cases such as those discussed above, where E2A targets are modified by the DNA binding domain of its fusion partner, the oncogenic role of E2A is no longer reflective of its physiological function.

\section{Physiological role of $E$ and Id proteins in $T$ cell development}

$\mathrm{E}$ proteins play crucial roles in early stages of $\mathrm{T}$ cell commitment, lineage specification and differentiation upon appropriate T cell receptor (TCR) expression $[20,25,86-$ 88]. In line with this, there is a significant developmental block at the early double negative (DN) stage in the absence of E2A [89,90]. E2A is found to activate Notch signaling to further induce T cell-specific genes like $T c f 1$, Gata3 and Bcll1b [26]. E2A blocks developmental progression at pre-TCR and TCR selection checkpoints such that only a productive signal can activate downstream events that upregulate $I d 3$ expression to ultimately overcome the E2A-mediated block [88]. A proliferative burst after pre-TCR selection is associated with the induction of cyclin D3 (Ccnd3) by E protein family member E47 [91,92]. Several other target genes that help E47 in regulating cell survival, cell cycle and maturation have been elucidated, and involve the induction of JAK/STAT pathway and SOC signaling [93].

\section{Tumor suppressive roles of E2A in $T$ cell lymphomas}

Malignant $\mathrm{T}$ cells can give rise to different kinds of lymphomas and leukemias in humans. A recurrent gene deletion is found in E2A in $70 \%$ of patients with Sezary syndrome, a type of $\mathrm{T}$ cell lymphoma, which is the first report demonstrating inactivating alterations in the E2A gene in human lymphomas [94]. This gene deletion results in upregulation of the cell cycle regulator $C d k 6$, which is a known E47 target [93] and can execute the anti-apoptotic and proliferative effects of $\mathrm{NOTCH}$ in these tumors. Interestingly, all chromosomal losses of E2A detected in these tumors were heterozygous. The authors propose that one copy of E2A is necessary for the survival of these cells, and therefore homozygous mutations are selected against. The remaining copy of WT E2A may also be posttranslationally degraded by NOTCH1 [94].

Anaplastic large cell lymphoma (ALCL) is a type of peripheral T cell lymphoma (PTCL), where gene translocations are commonly observed. It was reported that the translocation that gives rise to an NPM-ALK fusion protein, also leads to abnormal upregulation of genes that are proximal to the breakpoint, including $I d 2$. This $I d 2$ overexpression impairs E2A-mediated regulation of T cell specific genes like $C d 3, L c k, F y n, T c f 7, T b x 21$, and Gata3, explaining the loss of T cell phenotype observed in ALCL cases. This supports tumor suppressor activity of E2A that is sensitive to Id protein inhibition [95].

T-ALL, or $\mathrm{T}$ cell acute lymphoblastic leukemia, is a classic example for the role played by $\mathrm{E}$ and Id proteins in the tumorigenic process. Activation of the Tall (also known as SCL) or the Tal2 genes is often a major causal factor for T-ALL, and is achieved by translocation and other mechanisms in over 60\% of T-ALL patients [96-98]. TAL1 is a bHLH transcription factor that forms an obligate heterodimer with E2A and HEB. It is typically required for HSC generation, and is not expressed in the thymus. Human T-ALLs show no sign of changes in E2A expression, but it has long been hypothesized that TAL1 inactivates E2A or usurps its tumor suppressor activity to give rise to T-ALL. Similarly, $L y l l$ is another gene that is activated in T-ALL and can bind to E2A, but results in regulation of different target genes [89]. TAL1 and LYL1 are involved in the maintenance of short-term and longterm HSCs respectively, where they each function with $\mathrm{E}$ proteins in a complex. This may be reflective of gene targets that drive T-ALL [40]. The mechanisms of T-ALL tumorigenesis have been explored by using mouse models and human lymphoma cell lines. Aberrant TAL1 overexpression in human tumor as well as mouse models gives rise to a developmental block at the DP stage [98]. TAL1 is found to mediate lymphoma development through a regulatory complex that comprises of E2A, HEB, LMO1/ 2, GATA3, RUNX1 and TAL1, where the latter three transcription factors are also part of a positive autoregulatory loop. Knockdown of these components inhibits cell growth and induces apoptosis [98]. Haplo-insufficiency of either E2A or HEB leads to a block in development at the DN stage, and accelerated T-ALL development in mice with Tall overexpression [96]. However, the dosage of E proteins is critical for lymphomagenesis as both E2A and HEB are required for the TAL1 complex. Co-repression of typical E2A targets was also observed, partly mediated by the $\mathrm{mSin} 3 \mathrm{~A} / \mathrm{HDAC} 1$ complex.

A study done in the Jurkat T-ALL cell line, where Tall is overexpressed and complexed with E2A, found low E2A transcriptional activity for an E-box reporter gene. Further, cells transduced with E-T/2 (E2A-Tal1) to restore E protein activity, underwent growth arrest and apoptosis, supporting an inhibition model where Tall inhibits the downstream tumor suppressive genes of E2A, such as p21, which could not be induced in Jurkat T cells [97]. While some normal E2A targets were still conserved in T-ALL 
tumor cell lines, such as Ptcra, Notch3, Ragl/2 and Gfil, TAL1 was found to promote some genes that are otherwise suppressed by E2A and HEB, and vice versa. One of those genes, TRIB2, is normally repressed by $\mathrm{E}$ proteins, but upregulated in the context of TAL1 complex, perhaps through TAL1 and NOTCH1 activity. TRIB2 has been reported as an oncogene in AML, and has now been shown to be important for T-ALL survival through downstream activation of XIAP, inhibitor of apoptosis [98,99]. TRIB2 can also control the expression of TAL1 partners GATA3 and RUNX1, and destabilizes E2A through proteasomes [99]. These observations support the tumor suppressor role of E2A in T-ALL.

Independent of the tumor suppressor roles of E2A observed in T-ALL, it was observed that E2A-deficient mice exhibit an early block in $\mathrm{T}$ cell development and develop lymphomas derived from immature DP or SP thymocytes $[89,90,94]$. Tumors, but not premalignant cells, overexpress c-Myc, which can possibly be explained by the gain of an extra copy of chromosome 15 . But it is unclear if E2A and c-Myc work together, or if c-Myc is the sole culprit in this lymphoma model [89]. These thymocytes aren't hyperproliferating or resistant to apoptosis. Overexpression of E2A in cell lines derived from lymphomas in E2A-deficient mice led to programmed cell death in the cells rather than growth arrest [91]. On the other hand, homozygous knockout of IdI in these E2A null mice improved survival but they still failed to rescue the tumor phenotype. This can be explained by a dominant tumor suppressor role of E2A, rather than being a direct Id-mediated effect [90]. The function of Notch acting together with, or in opposition to $\mathrm{E} 2 \mathrm{~A}$ in $\mathrm{T}$ cell development is still open to debate [25]. Their role in E2Adeficient or $\mathrm{T}$ cell lymphomas is equally debatable $[100$ 104]. Notch has been proposed to represent a second hit in T-ALL as Notch 1 and Notch 3 are found to be aberrantly activated by translocations and somatic mutations in a large fraction of T-ALL cases, where the tumor depends on Notch signaling for survival [103]. Others have reported that Notch activity is not essential for tumorigenesis in $\mathrm{T}$ cell derived tumors with impaired E protein activity [101].

\section{Paradoxical role of Id proteins in $\mathrm{T}$ cell lymphomas}

Since E proteins were suggested to play tumor suppressive roles in T cell-derived human and murine cancer models, it was natural to assume the oncogenic roles of Id proteins in these contexts, except in T-ALL where TAL1 overexpression modifies E2A targets through Id-independent mechanisms. The overexpression of Id2 in ALCL, PTCL and multiple other types of $\mathrm{T}$ cell lymphomas, and its induction by Myc, supported this hypothesis [105]. In mouse models expressing an Id2 transgene, there is a developmental block at early steps of $\mathrm{T}$ cell development, accompanied by hyperproliferating $\mathrm{T}$ cell lymphomas in most mice [106]. These tumors have high level of $M y c$ expression upon malignant transformation, but not in premalignant stage, therefore c-Myc may be important for the tumor, but is not driven by Id 2 overexpression. Not all mice with the $I d 2$ transgene develop tumor, suggesting that it is an important but not sufficient event for causing tumorigenesis. It is likely that overexpression of $I d 2$ (or E protein deficiency) blocks further differentiation in proliferating cells, predisposing them to secondary mutations, that represent either early transformation events after which the T cells can independently rearrange their TCR, or divergent transformation events, that give rise to polyclonal tumors [106]. A similar phenotype is observed in Idl transgenic mice, such that there is a severe block at $\mathrm{T}$ cell progenitor step with massive apoptosis triggered in most $\mathrm{T}$ cells, ultimately leading to lymphoma development. c-Myc may play a role in this phenotype since it can function both as an oncogene, and inducer of apoptosis. Induction of p21 by E2A may partly be able to block cell cycle progression in these cells [107]. These studies support the oncogenic roles of Id proteins in T cell-derived lymphoma development.

In direct contrast, there is also strong evidence in favor of tumor suppressor roles played by Id proteins in a subset of lymphomas derived from innate-like T cells. Knocking out $I d 3$ in mice gives rise to $\gamma \delta \mathrm{T}$ cell lymphomas, resembling hepatosplenic $\gamma \delta \mathrm{T}$ cell lymphomas (HSTCL) in humans. There is no dysregulation of genes that are commonly found in $\alpha \beta$ T cell lymphomas, such as those described in the previous sections, including Lyll, Tall and $p 21$. However, an increase in Myc expression was observed among some samples [108]. We have recently found that Id2 and Id 3 also play tumor suppressor roles in invariant natural killer T (iNKT-) and innate-like tumors in mice [109]. These lymphomas develop much more rapidly than the $\gamma \delta \mathrm{T}$ cell lymphomas in Id3-deficient mice, and display signs of chromosomal instability. The dichotomy observed in the gene expression programs for premalignant innate-like T cells in these mice is interesting - there is both downregulation and upregulation of tumor suppressor, anti-proliferative and cell cycle arrest genes, demonstrating a somewhat "balanced" state. However, after a presumed second hit, lymphoma cells have enrichment for genes often dysregulated in cancers, cytokine-cytokine interaction genes and $\mathrm{Nf}-\mathrm{\kappa B}$ signaling, similar to pathways reported in human NK/T tumors. Similarly, deficiency of Id 2 and/or Id 3 in mice also causes an expansion of innate variant $\mathrm{T}_{\mathrm{FH}}$-like cells, and $\alpha \beta \mathrm{T}$ cell lymphomas in these Id2/Id3-deficient mice that display an increase in Myc expression and reduction in the tumor suppressor Cdkn2a $[88,110]$. There is evidence to suggest tumor suppressor functions of Id4 in T cell tumors. Exogenous expression of Id4 in lymphoid tumor cell lines induces caspasedependent apoptosis. Additionally, methylation is found 
at the Id4 promoter locus in multiple tumor models, including chronic lymphocytic leukemia (CLL), and a mouse model of T/NK acute lymphoblastic leukemia upon malignant transformation, that correlates with reduced Id4 expression and lower patient survival [111-114]. Therefore, Id proteins can play both oncogenic and tumor suppressive roles in lymphomagenesis of T cells.

\section{Concluding remarks}

Id proteins have classically been considered as oncogenes based on their ability to promote stem cell-like properties, and their overexpression in different tumors. In this review, we investigate evidence in favor of or against the presumed oncogenic roles of Id proteins in lymphocytes, with respect to their inhibition of E protein activity. An oncogene is typically defined as a gene, which when mutated, confers cells with properties that facilitate adoption of a tumorigenic program [4]. Id proteins can upregulate antiapoptotic and pro-survival factors that overcome programmed cell death, promoting tumorigenesis. In many cases, Id proteins are often dysregulated by upstream oncogenic events, such as Myc, Ras and Notch signaling, and also inhibited by tumor suppressor genes. The activation of Id3 by oncogenic Ras signaling leads to $\mathrm{E}$ protein inhibition, tipping the balance. This inhibition via Ras supports the role of $\mathrm{E}$ proteins as tumor suppressors $[13,25]$. However, overexpression of Id proteins is not enough to cause tumorigenesis in mice unless combined with anti-apoptotic genes $[11,15,115,116]$. It is also dangerous to draw conclusions about the oncogenic roles of $\mathrm{E}$ or Id proteins based on their expression levels or physiological activity, since these may be impaired or hijacked, irrespective of expression patterns. For instance, Id3 is overexpressed several fold in Burkitt's lymphoma samples [33-35], but its function of mediating E protein inhibition is blocked through mutations in $I d 3$ or $T c f 3$, revealing the tumor suppressive function, instead of the oncogenic role of Id3. Therefore, RNA expression data alone without validation of protein functions may not be sufficient to determine whether Id3 plays a tumor suppressing or promoting role.

A similar stringent criterion should also apply to the cases where Id proteins function as tumor suppressors. The observation of either loss-of-function mutations in Id3 or gain of function of E2A in Burkitt's lymphoma validates Id3's role as a tumor suppressor. Physiologically, E2A mediates germinal center B cell survival and function through critical genes, while the upregulation of Id proteins keeps their activity in check $[63,117]$. In the case of BL, the lack of E2A inhibition by mutated Id3 perpetrates a tonic BCR and PI3K signaling that drives GC B cellderived lymphomagenesis. Id 2 and/or Id 3 also play tumor suppressor roles to prevent lymphomagenesis of $\gamma \delta$, iNKT and innate-like $\mathrm{T}$ cells. In these studies, tumorigenesis can be attributed to direct dysregulation of cell cycle, NF- $\kappa B$, cytokine-cytokine receptor interaction and innate-like developmental genes by high E2A activity [108-110]. Interestingly, although most lymphomas found in Id3deficient mice are $\gamma \delta \mathrm{TCR}^{+}$, some morphologically identical tumors express typical B cell markers, B220 and CD19 in the absence T cell-related markers [108]. Even though it remains to be determined if these lymphomas are truly derived from B cells, this phenotype may somehow reflect the tumor suppressive role of Id3 in BL. Further, delineating the order and contribution of the predominant Id 3 and Myc mutations in BL patients toward pathogenesis will greatly enhance our understanding of the downstream pathways that drive malignant transformation of GC DZ B cells.

E proteins promote survival and proliferation in B cell progenitors, while they play the opposite role in DN3 T cell progenitors [25]. It is suggested that despite recognizing the same E-box motif in immature thymocytes and pro-B cells, the downstream targets are starkly different, and may be determined by cooperating transcription factors. This can ultimately determine their role in tumor, and can explain their tumor suppressor role in T cells but oncogenic role in B cell lymphomas [88]. It is important to further consider that E2A functions as a heterodimer in concert with HEB in $\mathrm{T}$ cells, but as a homodimer in B cells. Strangely, the fusion proteins E2A-HLF and E2A-PBX1 that are responsible for B cell-driven lymphomagenesis in humans, give rise to T cell lymphomas and acute myeloid leukemia in transgenic mice [82].

To summarize, Id proteins and E proteins are powerful regulators of cell cycle and senescence, allowing them to interchangeably play tumor suppressive and oncogenic roles. In almost all cases, simple dysregulation of $\mathrm{E}$ and Id proteins is not sufficient to cause tumors, and a secondary mutation hit is often required. It is possible that the dysregulation of $\mathrm{E}$ and Id proteins causes a growth arrest at a stage where most cells are cycling, leading to accumulation of mutations that predispose these cells to lymphomageneses. This predisposition to accumulating mutations to undergo malignant transformation, referred to as cellular pliancy, however, differs between different cell types and developmental stages. Here we summarized the various factors that determine the downstream targets of $\mathrm{E}$ and Id proteins, and therefore their function in physiological development, tumor suppression or tumorigenesis (Fig. 1). This includes important considerations such as the target cell type, dosage of $E$ proteins, or transient upregulation of Id proteins, and functional redundancy between family members. Given the complexity that determines the role of Id proteins in cancers, inhibition of Id proteins may be clinically beneficial in certain tumor settings, but not in others. 


\section{Compliance with ethics guidelines}

Sumedha Roy and Yuan Zhuang declare no conflict of interest. This manuscript is a review article and does not involve a research protocol requiring approval by the relevant institutional review board or ethics committee.

Open Access This article is distributed under the terms of the Creative Commons Attribution 4.0 International License (http:// creativecommons.org/licenses/by/4.0/), which permits unrestricted use, distribution, and reproduction in any medium, provided the appropriate credit is given to the original author(s) and the source, and a link is provided to the Creative Commons license, which indicates if changes are made.

\section{References}

1. Norton JD, Deed RW, Craggs G, Sablitzky F. Id helix-loop-helix proteins in cell growth and differentiation. Trends Cell Biol 1998; 8(2): 58-65

2. Lasorella A, Uo T, Iavarone A. Id proteins at the cross-road of development and cancer. Oncogene 2001; 20(58): 8326-8333

3. Sikder HA, Devlin MK, Dunlap S, Ryu B, Alani RM. Id proteins in cell growth and tumorigenesis. Cancer Cell 2003; 3(6): 525-530

4. Perk J, Iavarone A, Benezra R. Id family of helix-loop-helix proteins in cancer. Nat Rev Cancer 2005; 5(8): 603-614

5. Lasorella A, Benezra R, Iavarone A. The ID proteins: master regulators of cancer stem cells and tumour aggressiveness. Nat Rev Cancer 2014; 14(2): 77-91

6. Hasskarl J, Münger K. Id proteins - tumor markers or oncogenes? Cancer Biol Ther 2002; 1(2): 91-96

7. Roschger C, Cabrele C. The Id-protein family in developmental and cancer-associated pathways. Cell Commun Signal 2017; 15(1): 7

8. Benezra R, Davis RL, Lockshon D, Turner DL, Weintraub H. The protein Id: a negative regulator of helix-loop-helix DNA binding proteins. Cell 1990; 61(1): 49-59

9. Langlands K, Yin X, Anand G, Prochownik EV. Differential interactions of Id proteins with basic-helix-loop-helix transcription factors. J Biol Chem 1997; 272(32): 19785-19793

10. Israel MA, Hernandez MC, Florio M, Andres-Barquin PJ, Mantani A, Carter JH, Julin CM. Id gene expression as a key mediator of tumor cell biology. Cancer Res 1999; 59(7 Suppl): 1726s-1730s

11. Norton JD, Atherton GT. Coupling of cell growth control and apoptosis functions of Id proteins. Mol Cell Biol 1998; 18(4): 2371-2381

12. Wong YC, Wang X, Ling MT. Id-1 expression and cell survival. Apoptosis 2004; 9(3): 279-289

13. Engel I, Murre C. E2A proteins enforce a proliferation checkpoint in developing thymocytes. EMBO J 2004; 23(1): 202-211

14. Slattery C, Ryan MP, McMorrow T. E2A proteins: regulators of cell phenotype in normal physiology and disease. Int J Biochem Cell Biol 2008; 40(8): 1431-1436

15. Tang J, Gordon GM, Nickoloff BJ, Foreman KE. The helix-loophelix protein Id-1 delays onset of replicative senescence in human endothelial cells. Lab Invest 2002; 82(8): 1073-1079

16. Neuhold LA, Wold B. HLH forced dimers: tethering MyoD to E47 generates a dominant positive myogenic factor insulated from negative regulation by Id. Cell 1993; 74(6): 1033-1042

17. Deed RW, Armitage S, Norton JD. Nuclear localization and regulation of Id protein through an E protein-mediated chaperone mechanism. J Biol Chem 1996; 271(39): 23603-23606

18. Zhuang Y, Soriano P, Weintraub $\mathrm{H}$. The helix-loop-helix gene E2A is required for B cell formation. Cell 1994; 79(5): 875-884

19. Bain G, Maandag EC, Izon DJ, Amsen D, Kruisbeek AM, Weintraub BC, Krop I, Schlissel MS, Feeney AJ, van Roon M, van der Valk M, te Riele HPJ, Berns A, Murre C. E2A proteins are required for proper $\mathrm{B}$ cell development and initiation of immunoglobulin gene rearrangements. Cell 1994; 79(5): 885-892

20. Engel I, Johns C, Bain G, Rivera RR, Murre C. Early thymocyte development is regulated by modulation of E2A protein activity. $\mathrm{J}$ Exp Med 2001; 194(6): 733-745

21. Greenbaum S, Zhuang Y. Regulation of early lymphocyte development by E2A family proteins. Semin Immunol 2002; 14(6): 405-414

22. Zhuang Y, Jackson A, Pan L, Shen K, Dai M. Regulation of E2A gene expression in B-lymphocyte development. Mol Immunol 2004; 40(16): 1165-1177

23. Greenbaum S, Zhuang Y. Identification of E2A target genes in B lymphocyte development by using a gene tagging-based chromatin immunoprecipitation system. Proc Natl Acad Sci USA 2002; 99(23): 15030-15035

24. Lin YC, Jhunjhunwala S, Benner C, Heinz S, Welinder E, Mansson R, Sigvardsson M, Hagman J, Espinoza CA, Dutkowski J, Ideker T, Glass CK, Murre C. A global network of transcription factors, involving E2A, EBF1 and Foxo1, that orchestrates B cell fate. Nat Immunol 2010; 11(7): 635-643

25. Murre C. Helix-loop-helix proteins and lymphocyte development. Nat Immunol 2005; 6(11): 1079-1086

26. Miyazaki K, Miyazaki M, Murre C. The establishment of B versus T cell identity. Trends Immunol 2014; 35(5): 205-210

27. Kwon K, Hutter C, Sun Q, Bilic I, Cobaleda C, Malin S, Busslinger M. Instructive role of the transcription factor E2A in early B lymphopoiesis and germinal center B cell development. Immunity 2008; 28(6): 751-762

28. Herblot S, Aplan PD, Hoang T. Gradient of E2A activity in B-cell development. Mol Cell Biol 2002; 22(3): 886-900

29. Kee BL, Rivera RR, Murre C. Id3 inhibits B lymphocyte progenitor growth and survival in response to TGF- $\beta$. Nat Immunol 2001; 2(3): 242-247

30. Chen S, Miyazaki M, Chandra V, Fisch KM, Chang AN, Murre C. Id 3 orchestrates germinal center b cell development. Mol Cell Biol 2016; 36(20): 2543-2552

31. Boxer LM, Dang CV. Translocations involving c-myc and c-myc function. Oncogene 2001; 20(40): 5595-5610

32. Miles RR, Raphael M, McCarthy K, Wotherspoon A, Lones MA, Terrier-Lacombe MJ, Patte C, Gerrard M, Auperin A, Sposto R, Davenport V, Cairo MS, Perkins SL; SFOP/LMB96/CCG5961/ UKCCSG/NHL 9600 Study Group. Pediatric diffuse large B-cell lymphoma demonstrates a high proliferation index, frequent c-Myc protein expression, and a high incidence of germinal center subtype: report of the French-American-British (FAB) interna- 
tional study group. Pediatr Blood Cancer 2008; 51(3): 369-374

33. Love C, Sun Z, Jima D, Li G, Zhang J, Miles R, Richards KL, Dunphy CH, Choi WW, Srivastava G, Lugar PL, Rizzieri DA, Lagoo AS, Bernal-Mizrachi L, Mann KP, Flowers CR, Naresh KN, Evens AM, Chadburn A, Gordon LI, Czader MB, Gill JI, Hsi ED, Greenough A, Moffitt AB, McKinney M, Banerjee A, Grubor V, Levy S, Dunson DB, Dave SS. The genetic landscape of mutations in Burkitt lymphoma. Nat Genet 2012; 44(12): 1321-1325

34. Richter J, Schlesner M, Hoffmann S, Kreuz M, Leich E, Burkhardt B, Rosolowski M, Ammerpohl O, Wagener R, Bernhart SH, Lenze D, Szczepanowski M, Paulsen M, Lipinski S, Russell RB, AdamKlages S, Apic G, Claviez A, Hasenclever D, Hovestadt V, Hornig N, Korbel JO, Kube D, Langenberger D, Lawerenz C, Lisfeld J, Meyer K, Picelli S, Pischimarov J, Radlwimmer B, Rausch T, Rohde M, Schilhabel M, Scholtysik R, Spang R, Trautmann H, Zenz T, Borkhardt A, Drexler HG, Möller P, MacLeod RA, Pott C, Schreiber S, Trümper L, Loeffler M, Stadler PF, Lichter P, Eils R, Küppers R, Hummel M, Klapper W, Rosenstiel P, Rosenwald A, Brors B, Siebert R; ICGC MMML-Seq Project. Recurrent mutation of the ID3 gene in Burkitt lymphoma identified by integrated genome, exome and transcriptome sequencing. Nat Genet 2012; 44 (12): 1316-1320

35. Schmitz R, Young RM, Ceribelli M, Jhavar S, Xiao W, Zhang M, Wright G, Shaffer AL, Hodson DJ, Buras E, Liu X, Powell J, Yang Y, Xu W, Zhao H, Kohlhammer H, Rosenwald A, Kluin P, MüllerHermelink HK, Ott G, Gascoyne RD, Connors JM, Rimsza LM, Campo E, Jaffe ES, Delabie J, Smeland EB, Ogwang MD, Reynolds SJ, Fisher RI, Braziel RM, Tubbs RR, Cook JR, Weisenburger DD, Chan WC, Pittaluga S, Wilson W, Waldmann TA, Rowe M, Mbulaiteye SM, Rickinson AB, Staudt LM. Burkitt lymphoma pathogenesis and therapeutic targets from structural and functional genomics. Nature 2012; 490(7418): 116-120

36. Havelange V, Pepermans X, Ameye G, Théate I, Callet-Bauchu E, Barin C, Penther D, Lippert E, Michaux L, Mugneret F, Dastugue N, Raphaël M, Vikkula M, Poirel HA. Genetic differences between paediatric and adult Burkitt lymphomas. Br J Haematol 2016; 173(1): 137-144

37. Cato MH, Chintalapati SK, Yau IW, Omori SA, Rickert RC. Cyclin D3 is selectively required for proliferative expansion of germinal center B cells. Mol Cell Biol 2011; 31(1): 127-137

38. Peled JU, Yu JJ, Venkatesh J, Bi E, Ding BB, Krupski-Downs M, Shaknovich R, Sicinski P, Diamond B, Scharff MD, Ye BH. Requirement for cyclin D3 in germinal center formation and function. Cell Res 2010; 20(6): 631-646

39. Rohde M, Bonn BR, Zimmermann M, Lange J, Möricke A, Klapper W, Oschlies I, Szczepanowski M, Nagel I, Schrappe M; MMML-MYC-SYS Project; ICGC MMML-Seq Project, Loeffler M, Siebert R, Reiter A, Burkhardt B. Relevance of ID3-TCF3CCND3 pathway mutations in pediatric aggressive B-cell lymphoma treated according to the non-Hodgkin Lymphoma Berlin-Frankfurt-Münster protocols. Haematologica 2017; 102(6): 1091-1098

40. Kee BLE. E and ID proteins branch out. Nat Rev Immunol 2009; 9 (3): 175-184

41. Roschke V, Kopantzev E, Dertzbaugh M, Rudikoff S. Chromosomal translocations deregulating c-myc are associated with normal immune responses. Oncogene 1997; 14(25): 3011-3016

42. Nepal RM, Zaheen A, Basit W, Li L, Berger SA, Martin A. AID and RAG1 do not contribute to lymphomagenesis in Emu c-myc transgenic mice. Oncogene 2008; 27(34): 4752-4756

43. Scholtysik R, Kreuz M, Klapper W, Burkhardt B, Feller AC, Hummel M, Loeffler M, Rosolowski M, Schwaenen C, Spang R, Stein H, Thorns C, Trümper L, Vater I, Wessendorf S, Zenz T, Siebert R, Küppers R; Molecular Mechanisms in Malignant Lymphomas Network Project of Deutsche Krebshilfe. Detection of genomic aberrations in molecularly defined Burkitt's lymphoma by array-based, high resolution, single nucleotide polymorphism analysis. Haematologica 2010; 95(12): 2047-2055

44. Salaverria I, Martin-Guerrero I, Wagener R, Kreuz M, Kohler CW, Richter J, Pienkowska-Grela B, Adam P, Burkhardt B, Claviez A, Damm-Welk C, Drexler HG, Hummel M, Jaffe ES, Küppers R, Lefebvre C, Lisfeld J, Löffler M, Macleod RA, Nagel I, Oschlies I, Rosolowski M, Russell RB, Rymkiewicz G, Schindler D, Schlesner M, Scholtysik R, Schwaenen C, Spang R, Szczepanowski M, Trümper L, Vater I, Wessendorf S, Klapper W, Siebert R; Molecular Mechanisms in Malignant Lymphoma Network Project; Berlin-Frankfurt-Münster Non-Hodgkin Lymphoma Group. A recurrent $11 \mathrm{q}$ aberration pattern characterizes a subset of MYC-negative high-grade B-cell lymphomas resembling Burkitt lymphoma. Blood 2014; 123(8): 1187-1198

45. Campo E. New pathogenic mechanisms in Burkitt lymphoma. Nat Genet 2012; 44(12): 1288-1289

46. Forshell LP, Li Y, Forshell TZ, Rudelius M, Nilsson L, Keller U, Nilsson J. The direct Myc target Pim3 cooperates with other Pim kinases in supporting viability of Myc-induced B-cell lymphomas. Oncotarget 2011; 2(6): 448-460

47. Murphy DJ, Swigart LB, Israel MA, Evan GI. Id2 is dispensable for Myc-induced epidermal neoplasia. Mol Cell Biol 2004; 24(5): 2083-2090

48. Gao XZ, Zhao WG, Wang GN, Cui MY, Zhang YR, Li WC. Inhibitor of DNA binding 4 functions as a tumor suppressor and is targetable by 5-aza-2'-deoxycytosine with potential therapeutic significance in Burkitt's lymphoma. Mol Med Rep 2016; 13(2): 1269-1274

49. Spender LC, Inman GJ. TGF- $\beta$ induces growth arrest in Burkitt lymphoma cells via transcriptional repression of E2F-1. J Biol Chem 2009; 284(3): 1435-1442

50. Bakkebø M, Huse K, Hilden VI, Smeland EB, Oksvold MP. TGF$\beta$-induced growth inhibition in B-cell lymphoma correlates with Smad1/5 signalling and constitutively active p38 MAPK. BMC Immunol 2010; 11(1): 57

51. Reddy A, Zhang J, Davis NS, Moffitt AB, Love CL, Waldrop A, Leppa S, Pasanen A, Meriranta L, Karjalainen-Lindsberg ML, Norgaard P, Pedersen M, Gang AO, Hogdall E, Heavican TB, Lone W, Iqbal J, Qin Q, Li G, Kim SY, Healy J, Richards KL, Fedoriw Y, Bernal-Mizrachi L, Koff JL, Staton AD, Flowers CR, Paltiel O, Goldschmidt N, Calaminici M, Clear A, Gribben J, Nguyen E, Czader MB, Ondrejka SL, Collie A, Hsi ED, Tse E, AuYeung RKH, Kwong YL, Srivastava G, Choi WWL, Evens AM, Pilichowska M, Sengar M, Reddy N, Li S, Chadburn A, Gordon LI, Jaffe ES, Levy S, Rempel R, Tzeng T, Happ LE, Dave T, Rajagopalan D, Datta J, Dunson DB, and Dave SS. Genetic and functional drivers of diffuse large B cell lymphoma. Cell 2017; 171(2): p. 481-494e15

52. Dubois S, Viailly PJ, Mareschal S, Bohers E, Bertrand P, Ruminy P, Maingonnat C, Jais JP, Peyrouze P, Figeac M, Molina TJ, 
Desmots F, Fest T, Haioun C, Lamy T, Copie-Bergman C, Brière J, Petrella T, Canioni D, Fabiani B, Coiffier B, Delarue R, Peyrade F, Bosly A, André M, Ketterer N, Salles G, Tilly H, Leroy K, Jardin F. Next-generation sequencing in diffuse large B-cell lymphoma highlights molecular divergence and therapeutic opportunities: a LYSA study. Clin Cancer Res 2016; 22(12): 2919-2928

53. Momose S, Weißbach S, Pischimarov J, Nedeva T, Bach E, Rudelius M, Geissinger E, Staiger AM, Ott G, Rosenwald A. The diagnostic gray zone between Burkitt lymphoma and diffuse large B-cell lymphoma is also a gray zone of the mutational spectrum. Leukemia 2015; 29(8): 1789-1791

54. Gebauer N, Bernard V, Feller AC, Merz H. ID3 mutations are recurrent events in double-hit B-cell lymphomas. Anticancer Res 2013; 33(11): 4771-4778

55. Dave SS, Fu K, Wright GW, Lam LT, Kluin P, Boerma EJ, Greiner TC, Weisenburger DD, Rosenwald A, Ott G, Müller-Hermelink HK, Gascoyne RD, Delabie J, Rimsza LM, Braziel RM, Grogan TM, Campo E, Jaffe ES, Dave BJ, Sanger W, Bast M, Vose JM, Armitage JO, Connors JM, Smeland EB, Kvaloy S, Holte H, Fisher RI, Miller TP, Montserrat E, Wilson WH, Bahl M, Zhao H, Yang L, Powell J, Simon R, Chan WC, Staudt LM; Lymphoma/ Leukemia Molecular Profiling Project. Molecular diagnosis of Burkitt's lymphoma. N Engl J Med 2006; 354(23): 2431-2442

56. Recaldin T, Fear DJ. Transcription factors regulating B cell fate in the germinal centre. Clin Exp Immunol 2016; 183(1): 65-75

57. Ramezani-Rad P, Rickert RC. Murine models of germinal center derived-lymphomas. Curr Opin Immunol 2017; 45: 31-36

58. Basso K, Dalla-Favera R. Germinal centres and B cell lymphomagenesis. Nat Rev Immunol 2015; 15(3): 172-184

59. Dorsett Y, Robbiani DF, Jankovic M, Reina-San-Martin B, Eisenreich TR, Nussenzweig MC. A role for AID in chromosome translocations between c-myc and the IgH variable region. J Exp Med 2007; 204(9): 2225-2232

60. Pasqualucci LBhagat G, Jankovic M, Compagno M, Smith P, Muramatsu M, Honjo T, Morse HC, Nussenzweig MC 3rd, DallaFavera R. AID is required for germinal center-derived lymphomagenesis. Nat Genet 2008; 40(1): 108-112

61. Victora GD, Dominguez-Sola D, Holmes AB, Deroubaix S, DallaFavera R, Nussenzweig MC. Identification of human germinal center light and dark zone cells and their relationship to human Bcell lymphomas. Blood 2012; 120(11): 2240-2248

62. Schmitz R, Ceribelli M, Pittaluga S, Wright G, Staudt LM. Oncogenic mechanisms in Burkitt lymphoma. Cold Spring Harb Perspect Med 2014; 4(2): a014282

63. Gloury R, Zotos D, Zuidscherwoude M, Masson F, Liao Y, Hasbold J, Corcoran LM, Hodgkin PD, Belz GT, Shi W, Nutt SL, Tarlinton DM, Kallies A. Dynamic changes in Id3 and E-protein activity orchestrate germinal center and plasma cell development. J Exp Med 2016; 213(6): 1095-1111

64. Calado DP, Sasaki Y, Godinho SA, Pellerin A, Köchert K, Sleckman BP, de Alborán IM, Janz M, Rodig S, Rajewsky K. The cell-cycle regulator c-Myc is essential for the formation and maintenance of germinal centers. Nat Immunol 2012; 13(11): $1092-1100$

65. Dominguez-Sola D, Victora GD, Ying CY, Phan RT, Saito M, Nussenzweig MC, Dalla-Favera R. The proto-oncogene MYC is required for selection in the germinal center and cyclic reentry. Nat
Immunol 2012; 13(11): 1083-1091

66. Bemark M, Neuberger MS. By-products of immunoglobulin somatic hypermutation. Genes Chromosomes Cancer 2003; 38 (1): 32-39

67. Guikema JE, de Boer C, Haralambieva E, Smit LA, van Noesel CJ, Schuuring E, Kluin PM. IGH switch breakpoints in Burkitt lymphoma: exclusive involvement of noncanonical class switch recombination. Genes Chromosomes Cancer 2006; 45(9): 808819

68. Xu Z, Pone EJ, Al-Qahtani A, Park SR, Zan H, Casali P. Regulation of aicda expression and AID activity: relevance to somatic hypermutation and class switch DNA recombination. Crit Rev Immunol 2007; 27(4): 367-397

69. Basso K, Dalla-Favera R. Roles of BCL6 in normal and transformed germinal center B cells. Immunol Rev 2012; 247(1): 172-183

70. Cruz-Rodriguez N, Combita AL, Enciso LJ, Raney LF, Pinzon PL, Lozano OC, Campos AM, Peñaloza N, Solano J, Herrera MV, Zabaleta J, Quijano S. Prognostic stratification improvement by integrating ID1/ID3/IGJ gene expression signature and immunophenotypic profile in adult patients with B-ALL. J Exp Clin Cancer Res 2017; 36(1): 37

71. Bellido M, Aventín A, Lasa A, Estivill C, Carnicer MJ, Pons C, Matías-Guiu X, Bordes R, Baiget M, Sierra J, Nomdedéu JF. Id4 is deregulated by a $\mathrm{t}(6 ; 14)(\mathrm{p} 22 ; \mathrm{q} 32)$ chromosomal translocation in a B-cell lineage acute lymphoblastic leukemia. Haematologica 2003; 88(9): 994-1001

72. Mandelbaum J, Bhagat G, Tang H, Mo T, Brahmachary M, Shen Q, Chadburn A, Rajewsky K, Tarakhovsky A, Pasqualucci L, Dalla-Favera R. BLIMP1 is a tumor suppressor gene frequently disrupted in activated B cell-like diffuse large B cell lymphoma. Cancer Cell 2010; 18(6): 568-579

73. Husson H, Carideo EG, Neuberg D, Schultze J, Munoz O, Marks PW, Donovan JW, Chillemi AC, O'Connell P, Freedman AS. Gene expression profiling of follicular lymphoma and normal germinal center B cells using cDNA arrays. Blood 2002; 99(1): 282-289

74. Renné C, Martin-Subero JI, Eickernjäger M, Hansmann ML, Küppers R, Siebert R, Bräuninger A. Aberrant expression of ID2, a suppressor of B-cell-specific gene expression, in Hodgkin's lymphoma. Am J Pathol 2006; 169(2): 655-664

75. Mathas S, Janz M, Hummel F, Hummel M, Wollert-Wulf B, Lusatis S, Anagnostopoulos I, Lietz A, Sigvardsson M, Jundt F, Jöhrens K, Bommert K, Stein H, Dörken B. Intrinsic inhibition of transcription factor E2A by HLH proteins ABF-1 and Id 2 mediates reprogramming of neoplastic B cells in Hodgkin lymphoma. Nat Immunol 2006; 7(2): 207-215

76. Küppers R, Bräuninger A. Reprogramming of the tumour B-cell phenotype in Hodgkin lymphoma. Trends Immunol 2006; 27(5): 203-205

77. Zhao P, Lu Y, Liu L, Zhong M. Aberrant expression of ID2 protein and its correlation with EBV-LMP1 and P16(INK4A) in classical Hodgkin lymphoma in China. BMC Cancer 2008; 8(1): 379

78. Ikeda J, Wada N, Nojima S, Tahara S, Tsuruta Y, Oya K, Morii E. ID1 upregulation and FoxO3a downregulation by Epstein-Barr virus-encoded LMP1 in Hodgkin's lymphoma. Mol Clin Oncol 2016; 5(5): 562-566 
79. Lietz A, Janz M, Sigvardsson M, Jundt F, Dörken B, Mathas S. Loss of bHLH transcription factor E2A activity in primary effusion lymphoma confers resistance to apoptosis. Br J Haematol 2007; 137(4): 342-348

80. Liu TY, Chen SU, Kuo SH, Cheng AL, Lin CW. E2A-positive gastric MALT lymphoma has weaker plasmacytoid infiltrates and stronger expression of the memory B-cell-associated miR-223: possible correlation with stage and treatment response. Mod Pathol 2010; 23(11): 1507-1517

81. Seidel MG, Look AT. E2A-HLF usurps control of evolutionarily conserved survival pathways. Oncogene 2001; 20(40): 5718-5725

82. Yoshihara T, Inaba T, Shapiro LH, Kato JY, Look AT. E2A-HLFmediated cell transformation requires both the trans-activation domains of E2A and the leucine zipper dimerization domain of HLF. Mol Cell Biol 1995; 15(6): 3247-3255

83. Kamps MP, Baltimore D. E2A-Pbx1, the $\mathrm{t}(1 ; 19)$ translocation protein of human pre-B-cell acute lymphocytic leukemia, causes acute myeloid leukemia in mice. Mol Cell Biol 1993; 13(1): 351357

84. Dedera DA, Waller EK, LeBrun DP, Sen-Majumdar A, Stevens ME, Barsh GS, Cleary ML. Chimeric homeobox gene E2A-PBX1 induces proliferation, apoptosis, and malignant lymphomas in transgenic mice. Cell 1993; 74(5): 833-843

85. Nourse J, Mellentin JD, Galili N, Wilkinson J, Stanbridge E, Smith $\mathrm{SD}$, Cleary ML. Chromosomal translocation $\mathrm{t}(1 ; 19)$ results in synthesis of a homeobox fusion mRNA that codes for a potential chimeric transcription factor. Cell 1990; 60(4): 535-545

86. Engel I, Murre C. The function of E- and Id proteins in lymphocyte development. Nat Rev Immunol 2001; 1(3): 193-199

87. Murre C. Role of helix-loop-helix proteins in lymphocyte development. Cold Spring Harb Symp Quant Biol 1999; 64(0): $39-44$

88. Miyazaki M, Rivera RR, Miyazaki K, Lin YC, Agata Y, Murre C. The opposing roles of the transcription factor E2A and its antagonist Id3 that orchestrate and enforce the naive fate of $\mathrm{T}$ cells. Nat Immunol 2011; 12(10): 992-1001

89. Bain G, Engel I, Robanus Maandag EC, te Riele HP, Voland JR, Sharp LL, Chun J, Huey B, Pinkel D, Murre C. E2A deficiency leads to abnormalities in $\alpha \beta$ T-cell development and to rapid development of T-cell lymphomas. Mol Cell Biol 1997; 17(8): 4782-4791

90. Yan W, Young AZ, Soares VC, Kelley R, Benezra R, Zhuang Y. High incidence of T-cell tumors in E2A-null mice and E2A/Id1 double-knockout mice. Mol Cell Biol 1997; 17(12): 7317-7327

91. Engel I, Murre C. Ectopic expression of E47 or E12 promotes the death of E2A-deficient lymphomas. Proc Natl Acad Sci USA 1999; 96(3): 996-1001

92. Sicinska E, Aifantis I, Le Cam L, Swat W, Borowski C, Yu Q, Ferrando AA, Levin SD, Geng Y, von Boehmer H, Sicinski P. Requirement for cyclin D3 in lymphocyte development and $\mathrm{T}$ cell leukemias. Cancer Cell 2003; 4(6): 451-461

93. Schwartz R, Engel I, Fallahi-Sichani M, Petrie HT, Murre C. Gene expression patterns define novel roles for E47 in cell cycle progression, cytokine-mediated signaling, and T lineage development. Proc Natl Acad Sci USA 2006; 103(26): 9976-9981

94. Steininger A, Möbs M, Ullmann R, Köchert K, Kreher S, Lamprecht B, Anagnostopoulos I, Hummel M, Richter J, Beyer
M, Janz M, Klemke CD, Stein H, Dörken B, Sterry W, Schrock E, Mathas S, Assaf C. Genomic loss of the putative tumor suppressor gene E2A in human lymphoma. J Exp Med 2011; 208(8): 15851593

95. Mathas S, Kreher S, Meaburn KJ, Jöhrens K, Lamprecht B, Assaf C, Sterry W, Kadin ME, Daibata M, Joos S, Hummel M, Stein H, Janz M, Anagnostopoulos I, Schrock E, Misteli T, Dörken B. Gene deregulation and spatial genome reorganization near breakpoints prior to formation of translocations in anaplastic large cell lymphoma. Proc Natl Acad Sci USA 2009; 106(14): 5831-5836

96. O’Neil J, Shank J, Cusson N, Murre C, Kelliher M. TAL1/SCL induces leukemia by inhibiting the transcriptional activity of E47/ HEB. Cancer Cell 2004; 5(6): 587-596

97. Park ST, Nolan GP, Sun XH. Growth inhibition and apoptosis due to restoration of E2A activity in $\mathrm{T}$ cell acute lymphoblastic leukemia cells. J Exp Med 1999; 189(3): 501-508

98. Sanda T, Lawton LN, Barrasa MI, Fan ZP, Kohlhammer H, Gutierrez A, Ma W, Tatarek J, Ahn Y, Kelliher MA, Jamieson CH, Staudt LM, Young RA, Look AT. Core transcriptional regulatory circuit controlled by the TAL1 complex in human T cell acute lymphoblastic leukemia. Cancer Cell 2012; 22(2): 209-221

99. Tan SH, Yam AW, Lawton LN, Wong RW, Young RA, Look AT, Sanda T. TRIB2 reinforces the oncogenic transcriptional program controlled by the TAL1 complex in T-cell acute lymphoblastic leukemia. Leukemia 2016; 30(4): 959-962

100. Spaulding C, Reschly EJ, Zagort DE, Yashiro-Ohtani Y, Beverly LJ, Capobianco A, Pear WS, Kee BL. Notch1 co-opts lymphoid enhancer factor 1 for survival of murine T-cell lymphomas. Blood 2007; 110(7): 2650-2658

101. Wang HC, Peng V, Zhao Y, Sun XH. Enhanced Notch activation is advantageous but not essential for T cell lymphomagenesis in Id1 transgenic mice. PLoS One 2012; 7(2): e32944

102. Grabher C, von Boehmer H, Look AT. Notch 1 activation in the molecular pathogenesis of T-cell acute lymphoblastic leukaemia. Nat Rev Cancer 2006; 6(5): 347-359

103. Reschly EJ, Spaulding C, Vilimas T, Graham WV, Brumbaugh RL, Aifantis I, Pear WS, Kee BL. Notch1 promotes survival of E2A-deficient $\mathrm{T}$ cell lymphomas through pre- $\mathrm{T}$ cell receptordependent and-independent mechanisms. Blood 2006; 107(10): 4115-4121

104. Talora C, Campese AF, Bellavia D, Pascucci M, Checquolo S, Groppioni M, Frati L, von Boehmer H, Gulino A, Screpanti I. PreTCR-triggered ERK signalling-dependent downregulation of E2A activity in Notch3-induced T-cell lymphoma. EMBO Rep 2003; 4 (11): 1067-1072

105. Cotta CV, Leventaki V, Atsaves V, Vidaki A, Schlette E, Jones D, Medeiros LJ, Rassidakis GZ. The helix-loop-helix protein Id2 is expressed differentially and induced by myc in T-cell lymphomas. Cancer 2008; 112(3): 552-561

106. Morrow MA, Mayer EW, Perez CA, Adlam M, Siu G. Overexpression of the helix-loop-helix protein Id2 blocks $\mathrm{T}$ cell development at multiple stages. Mol Immunol 1999; 36(8): 491503

107. Kim D, Peng XC, Sun XH. Massive apoptosis of thymocytes in Tcell-deficient Id1 transgenic mice. Mol Cell Biol 1999; 19(12): $8240-8253$

108. Li J, Maruyama T, Zhang P, Konkel JE, Hoffman V, Zamarron B, 
Chen W. Mutation of inhibitory helix-loop-helix protein Id 3 causes $\gamma \delta$ T-cell lymphoma in mice. Blood 2010; 116(25): 5615-5621

109. Li J, Roy S, Kim YM, Li S, Zhang B, Love C, Reddy A, Rajagopalan D, Dave S, Diehl AM, Zhuang Y. Id2 collaborates with Id3 to suppress invariant NKT and innate-like tumors. J Immunol 2017; 198(8): 3136-3148

110. Miyazaki M, Miyazaki K, Chen S, Chandra V, Wagatsuma K, Agata Y, Rodewald HR, Saito R, Chang AN, Varki N, Kawamoto $\mathrm{H}$, Murre $\mathrm{C}$. The E-Id protein axis modulates the activities of the PI3K-AKT-mTORC1-Hifla and c-myc/p19Arf pathways to suppress innate variant TFH cell development, thymocyte expansion, and lymphomagenesis. Genes Dev 2015; 29(4): 409-425

111. Yu L, Liu C, Vandeusen J, Becknell B, Dai Z, Wu YZ, Raval A, Liu TH, Ding W, Mao C, Liu S, Smith LT, Lee S, Rassenti L, Marcucci G, Byrd J, Caligiuri MA, Plass C. Global assessment of promoter methylation in a mouse model of cancer identifies ID4 as a putative tumor-suppressor gene in human leukemia. Nat Genet 2005; 37(3): 265-274

112. Chen SS, Claus R, Lucas DM, Yu L, Qian J, Ruppert AS, West DA, Williams KE, Johnson AJ, Sablitzky F, Plass C, Byrd JC. Silencing of the inhibitor of DNA binding protein 4 (ID4) contributes to the pathogenesis of mouse and human CLL. Blood 2011; 117(3): 862871

113. Cen J, Shen J, Wang X, Kang H, Wang L, Sun L, Li Y, Yu L. Association between lymphoma prognosis and aberrant methylation of ID4 and ZO-1 in bone marrow and paraffin-embedded lymphoma tissues of treatment-naive patients. Oncol Rep 2013; 30(1): 455-461

114. Hagiwara K, Nagai H, Li Y, Ohashi H, Hotta T, Saito H. Frequent DNA methylation but not mutation of the ID4 gene in malignant lymphoma. J Clin Exp Hematop 2007; 47(1): 15-18

115. Alani RM, Hasskarl J, Grace M, Hernandez MC, Israel MA, Münger K. Immortalization of primary human keratinocytes by the helix-loop-helix protein, Id-1. Proc Natl Acad Sci USA 1999; 96 (17): 9637-9641

116. Nickoloff BJ, Chaturvedi V, Bacon P, Qin JZ, Denning MF, Diaz MO. Id-1 delays senescence but does not immortalize keratinocytes. J Biol Chem 2000; 275(36): 27501-27504

117. Wöhner M, Tagoh H, Bilic I, Jaritz M, Poliakova DK, Fischer M, Busslinger M. Molecular functions of the transcription factors E2A and E2-2 in controlling germinal center B cell and plasma cell development. J Exp Med 2016; 213(7): 1201-1221 